\title{
Subject Characteristics Group Identifier
}

National Cancer Institute

\section{Source}

National Cancer Institute. Subject Characteristics Group Identifier. NCI Thesaurus. Code C83399.

A character or string that represents a subject characteristics group. 